\title{
Validity of Neutrophil/Lymphocyte and Platelet/Lymphocyte Ratio in the Diagnosis of Pulmonary Embolism in Patients with Renal Disorder
}

\author{
Renal Fonksiyon Bozukluğu Olan Hastalarda Nötrofil/Lenfosit ve Platelet/Lenfosit \\ Oranlarının Pulmoner Emboli Tanısında Kullanılabilirliği
}

Ezgi Türkoğlu, (1) Mehmet Emin Pișkinpașa

University of Health Sciences Turkey, İstanbul Training and Research Hospital, Clinic of Internal Medicine, İstanbul, Turkey

\begin{abstract}
Introduction: Acute pulmonary embolism (APE) is a common and sometimes fatal form of venous thromboembolism. The fact that patients do not consult with a specific clinical picture and accompanying comorbid conditions make the diagnosis difficult. Chronic renal failure is one of the comorbid conditions with increased susceptibility to thrombosis. Due to clinical presentation variabilities, the limited use of the d-dimer test in patients with renal dysfunction, and the limitation of use of computed tomography (CT) angiography due to potential renal side effects, an easily accessible, inexpensive, sensitive and specific guide laboratory parameter within acceptable limits is needed in the diagnosis of patients with impaired renal function. In this study, neutrophil/lymphocyte ratios (NLR) and platelet/lymphocyte ratios (PLR) will be compared between two patient groups with and without renal dysfunction and APE attack. It is aimed to demonstrate the usability of these rates together with clinical, laboratory and radiological evaluations in the diagnosis of pulmonary embolism.
\end{abstract}

Methods: In the selection of patient groups, the retrospective files of patients with chronic renal failure who applied to the emergency service of our hospital between January 2015 and 2019 and then were diagnosed with APE were examined. The control group consist of the patients with chronic renal failure who applied to the nephrology and internal medicine outpatient clinic without any additional pathology. Information such as gender, age, existing diseases, laboratory tests such as hemogram, D-dimer, troponin, creatinine glomerular filtration rate, lower extremity venous Doppler ultrasonography and thorax $C T$ angiography results of the patients were recorded. NLR and PLR ratios were calculated in all groups. The results were evaluated with SPSS.

Results: NLR and PLR values were found to be significantly higher in the case group diagnosed with pulmonary embolism $(p=0.000)$. At NLR 3.50 cut-off value, sensitivity was $70.6 \%$, positive prediction was $84.6 \%$, specificity was $86.8 \%$, and

\section{ÖZ}

Amaç: Akut pulmoner emboli (APE); yaygın ve bazen ölümcül olan bir venöz tromboemboli şeklidir. Hastaların spesifik bir klinik tabloyla bașvurmamaları ve eșlik eden komorbid durumlar tanıyı güçleștirir. Kronik böbrek yetmezliği de tromboza yatkınlığın arttığı komorbid durumlardandır. Klinik prezantasyon değișkenlikleri, D-dimer testinin renal disfonksiyonlu hastalarda kullanım kısıtlılığı, bilgisayarlı tomografi (BT) anjiyografinin olası renal yan etkilerinden dolayı kullanım kısıtı nedeniyle renal fonksiyonları bozuk hastaların tanısında, kolay ulaşılabilir, ucuz, kabul edilebilir sınırlarda sensitif ve spesifik bir kılavuz laboratuvar parametresine intiyaç duyulmaktadır. Bu çalışmada renal fonksiyon bozukluğu mevcut ve APE atağı geçiren ve geçirmeyen iki hasta grubu arasında nötrofil/lenfosit oranları (NLR) ve platelet/lenfosit oranları (PLR) karşılaștırılacaktır. Bu oranların pulmoner emboli tanısındaki klinik, laboratuvar ve radyolojik değerlendirmelerle birlikte kullanılabilirliğinin gösterilmesi amaçlanmıștır.

Yöntemler: Hasta gruplarının seçiminde Ocak 2015-2019 tarihleri arasında hastanemiz acil servisine bașvurarak APE tanısı almış, kronik böbrek yetmezliği olan hastaların geriye dönük dosyaları incelenmiştir. Kontrol grubu olarak ise ek patolojisiolmayan, nefrolojive dahiliye polikliniğine başvurmuş, kronik renal yetmezliği bulunan hastalar alınmıștır. Hastaların cinsiyet, yaş, mevcut hastalıkları, laboratuvar tetkiklerinden hemogram, D-dimer, troponin, kreatinin glomerüler filtrasyon hızı, alt ekstremite venöz Doppler ultrasonografi ve toraks BT anjiyografi sonuçları kaydedilmiștir. Tüm gruplarda NLR ve PLR oranları hesaplanmıştır. Sonuçlar SPSS ile değerlendirilmiştir.

Bulgular: Pulmoner emboli tanılı olgu grubunda NLR ve PLR değerleri anlamlı olarak daha yüksek bulunmuştur $(p=0,000)$. NLR 3,50 cut-off değerinde duyarlık \%70,6, pozitif kestirim \%84,6, özgüllük \%86,8, negatif kestirim \%74,2 olarak bulunmuștur. PLR 125 cut-off değerinde duyarlık \%68,8, pozitif
Address for Correspondence/Yazıșma Adresi: Mehmet Emin Pișkinpaşa MD, University of Health Sciences Turkey,

İstanbul Training and Research Hospital, Clinic of Internal Medicine, İstanbul, Turkey

Phone: +90 5057980854 E-mail: episkinpasa@yahoo.com.tr ORCID ID: orcid.org/0000-0003-2103-4368

Cite this article as/Atıf: Türkoğlu E, Pișkinpașa ME. Validity of Neutrophil/Lymphocyte and Platelet/

Lymphocyte Ratio in the Diagnosis of Pulmonary Embolism in Patients with Renal Disorder.

İstanbul Med J 2021; 22(4): 280-6.

(C) Copyright 2021 by the University of Health Sciences Turkey, Istanbul Training and Research Hospital/istanbul Medical Journal published by Galenos Publishing House.

(C) Telif Hakkı 2021 Sağıı Bilimleri Üniversitesi Istanbul Ĕgitim ve Araştırma Hastanesi/Istanbul Tıp Dergisi, Galenos Yayınevi tarafından basılmıștır.
Received/Geliș Tarihi: 19.08.2021 Accepted/Kabul Tarihi: 06.09.2021 
negative prediction was $74.2 \%$. Sensitivity was $68.8 \%$, positive prediction was $67.0 \%$, specificity was $65.1 \%$, negative prediction was $67 \%$ at PLR 125 cut-off value.

Conclusion: NLR and PLR values can be used in addition to clinical, laboratory and imaging methods in the diagnosis of APE in patients with chronic renal failure and can give results that may help the clinician. However, more comprehensive studies should be conducted with larger case groups.

Keywords: Acute pulmonary embolism, chronic renal failure, NLR, PLR kestirim \%67,0, özgüllük \%65,1, negatif kestirim \%67 olarak saptanmıștır.

Sonuç: Kronik böbrek yetmezlikli hastalarda, APE tanısında NLR ve PLR değerleri klinik, laboratuvar ve görüntüleme yöntemlerinin yanında kullanılabilir ve klinisyene yardımcı olabilecek sonuçlar verebilir. Fakat daha geniş olgu gruplarıyla daha kapsamlı çalıșmalar yapılmalıdır.

Anahtar Kelimeler: Akut pulmoner emboli, kronik renal yetmezlik, NLR, PLR

\section{Introduction}

Acute pulmonary embolism (APE) is a common and sometimes fatal form of venous thromboembolism (VTE). Despite all the improvements in diagnosis and treatment, it can be mortal. D-dimer test, lower extremity Doppler ultrasonography, thorax computed tomography (CT) angiography and ventilation perfusion (V/Q) scintigraphy can be used for diagnosis. Geneva and Wells scoring and D-dimer are used together in the diagnosis of possible pulmonary embolism. These scores and the D-dimer test were found to be safe, especially in young patients who do not have any additional disease (1).

Tendency to thrombosis seen in chronic renal failure is increased due to decreased fibrinolytic activity, endothelial damage, decreased pro-coagulant factors and increased anticoagulant factors (2). In this patient group, the diagnostic value of the D-dimer test in the diagnosis of pulmonary embolism is lower than in patients without renal dysfunction. D-dimer level increases in cases of decreased renal function due to decreased elimination and increased coagulation activation, and its specificity decreases significantly in these patients (3).

Pulmonary CT angiography is the gold standard diagnostic test in the diagnosis of APE, but the contrast agent used during the process worsens renal functions. In the diagnosis of patients with impaired renal function, due to clinical presentation variability, limitation of use of the d-dimer test in patients with renal dysfunction, and reservations due to possible renal side effects of a standard diagnostic tool such as CT angiography, there is a need for an easily applicable, low cost, sensitive and specific guide laboratory parameter within acceptable limits. Inflammation has been shown to play an important role in cases of VTE. This study was designed to predict the utility of neutrophil/ lymphocyte (NLR) and platelet/lymphocyte ratios (PLR), which are markers of inflammation, in the diagnosis of pulmonary embolism in patients with chronic renal failure.

\section{Methods}

The study protocol was approved by the University of Health Sciences Turkey, İstanbul Training and Research Hospital Local Ethics Committee (approval number: 1825, date: 10.05.2019).

This is planned as a retrospective, randomized and controlled study. Patients with chronic renal failure who applied to the emergency outpatient clinic of our hospital between January 2015 and 2019 and were diagnosed with APE were included in the study.
Inclusion criteria: Age, glomerular filtration rate (eGFR) $<60-90 \mathrm{~mL} /$ $\min / 1.73$, and structural abnormalities detected by renal damage markers or radiologically (structural abnormalities or urinary sediment abnormalities or albuminuria albumin-to-creatinine ratio $>30 \mathrm{mg} /$ gr detected with imaging methods more than 3 months) and APE confirmed and specified by computed tomographic angiography, both patients receiving hemodialysis were included in the study.

Exclusion criteria: Patients with solid organ malignancies, patients with acute and/or chronic infections, and patients with drug use that would affect the parameters in the hemogram were excluded from the study.

Patients who were followed up with the diagnosis of chronic renal failure in the nephrology and internal diseases outpatient clinics of our age-gender matched hospital, who had not had an embolism before, were included in the study as the control group.

The patients' age, gender, current diseases, hemogram, D-dimer, troponin, creatinine and eGFR values, lower extremity venous Doppler USG and pulmonary CT angiography results were recorded.

Results were grouped according to their eGFR values: below $30 \mathrm{~mL} /$ $\min / 1.73 \mathrm{~m}^{2}$, between $30-60 \mathrm{~mL} / \mathrm{min} / 1.73 \mathrm{~m}^{2}$ and between $60-90 \mathrm{~mL} /$ $\min / 1.73 \mathrm{~m}^{2}$. Patients with pulmonary embolism were divided into groups according to severity and anatomical localization as massive and submassive, segmental and subsegmental, unilateral and bilateral. In the case group consisting of patients with pulmonary embolism, those with diabetes mellitus (DM), hypertension and heart failure were recorded and they were also examined for the presence of deep vein thrombosis and were grouped as present or absent deep venous thrombosis (DVT).

\section{Statistical Analysis}

In the descriptive statistics of the data, mean, standard deviation, median minimum and maximum, frequency and ratio values were used. The distribution of variables was measured with the KolmogorovSmirnov test. Independent sample t-test and Mann-Whitney $U$ test were used in the analysis of quantitative independent data. Chi-square test was used in the analysis of qualitative independent data, and Fischer's test was used when the chi-square test conditions were not met. The effect level was investigated with the receiver operating characteristic curve. SPSS 22.0 program was used in the analysis. 


\section{Results}

A total of 215 patients, aged between 18-75 years, who met the inclusion criteria, were included in the study, 109 as the case group and 106 as the control group.

$41.3 \%(n=45)$ of the case group were male and $58.7 \%(n=64)$ were female. Of the control group, 39.6\% $(n=42)$ were male and $60.4 \%(n=64)$ was female. There was no significant difference between the groups in terms of gender frequencies $(p=0.804)$.

In the case group, $28.4 \%(n=31)$ of the subjects had type $2 \mathrm{DM}, 47.7 \%$ $(n=52)$ had hypertension and $27.5 \%(n=30)$ had heart failure.

While the mean hemoglobin value in the case group was $11.9 \pm 1.9 \mathrm{~g} /$ $\mathrm{dL}$, it was $12.6 \pm 1.7 \mathrm{~g} / \mathrm{dL}$ in the control group. The hemoglobin value in the case group was significantly lower than the in the control group $(p=0.021)$.

In the case group, $16.5 \%(n=18)$ of the subjects had eGFR below 30,33\% $(n=37)$ had an eGFR between 30-60, 49.5\% $(n=54)$ had an eGFR value between 60-90. In the control group, $16 \%(n=17)$ of the subjects had an eGFR value below 30, 34.9\% $(n=37)$ had an eGFR value between 30-60, 49.1\% $(n=52)$ had an eGFR value between 60-90. GFR value did not differ significantly between groups with and without APE diagnosis ( $p=0.988)$.

The mean NLR in the case group was $6.5 \pm 6.8$, the median value was 4.4. Mean NLR in the control group was $2.4 \pm 2.2$; the median value was 2.1. In the case group, the mean PLR was 197.5 \pm 174.2 ; the median value was 162.8. The mean PLR in the control group was $116.0 \pm 42.1$, and the median value was 110.1 (Table 1). NLR and PLR values in the case group were significantly higher than the control group $(p=0.000)$ (Table 2).
At the NLR cut-off value of 3.50 , the sensitivity was $70.6 \%$, the positive prediction was $84.6 \%$, the specificity was $86.8 \%$, and the negative prediction was $74.2 \%$. At the PLR 125 cut-off value, the sensitivity was $68.8 \%$, the positive prediction was $67.0 \%$, the specificity was $65.1 \%$, and the negative prediction was $67 \%$ (Table 3 ).

The mean NLR of patients with massive pulmonary embolism was $6.8 \pm 6.4$. The mean NLR of patients with submassive pulmonary embolism was found to be $6.3 \pm 7.1$. There was no significant difference in NLR values between massive and submassive pulmonary embolism groups $(p=0.372)$ (Figure 1).

The mean NLR value of patients with segmental pulmonary embolism was $6.6 \pm 6.6$. The mean NLR value of patients with subsegmental pulmonary embolism was $6.3 \pm 7.8$. There was no significant difference in NLR values between cases with segmental and subsegmental pulmonary embolism $(p=0.349)$.

The mean NLR of cases with unilateral pulmonary embolism was found to be $6.5 \pm 5.8$, and cases with bilateral pulmonary embolism were found as 6.5 \pm 7.5 . NLR values did not differ significantly between cases with unilateral pulmonary embolism and bilateral pulmonary embolism $(p=0.360)$ (Figure 2).

The mean PLR of patients with massive pulmonary embolism was 193.9 \pm 116.0 . The mean PLR of patients with submassive pulmonary embolism was 199.8 \pm 204.2 . There was no significant difference in PLR values between massive and submassive pulmonary embolism groups $(p=0.660)$.

The mean PLR value of patients with segmental pulmonary embolism was 203.6 \pm 190.0 . The mean PLR value of patients with subsegmental

Table 1. Comparison of leukocyte, neutrophil, lymphocyte and platelet values of case and control groups

\begin{tabular}{|l|l|l|l|}
\hline Variable & Case $(\mathbf{n}=\mathbf{1 0 9})^{*}$ & Control $(\mathbf{n}=106)^{*}$ & $\mathbf{p}^{* *}$ \\
\hline Leukocytes $\left(\right.$ count $\left./ \mathrm{mm}^{3}\right)$ & $10372 \pm 5492$ & $7775 \pm 2065$ & 0.001 \\
\hline Neutrophil $\left(\right.$ count $\left./ \mathrm{mm}^{3}\right)$ & $7801 \pm 5244$ & $5431 \pm 8850$ & 0.001 \\
\hline Lymphocyte $\left(\right.$ count $\left./ \mathrm{mm}^{3}\right)$ & $1665 \pm 1029$ & $2360 \pm 1059$ & 0.001 \\
\hline Platelet $\left(1000^{*}\right)\left(\right.$ count $\left./ \mathrm{mm}^{3}\right)$ & $244 \pm 96$ & $247 \pm 68$ & 0.319 \\
\hline
\end{tabular}

"The mean \pm standard deviation is given, ${ }^{* *} p<0.05$ was taken as the cut-off value of significance

Table 2. NLR and PLR values in case and control groups

ROC curve

\begin{tabular}{|l|l|l|l|}
\hline & Area & Area under curve & $\mathbf{p}$ \\
\hline NLR & 0.808 & $0.747-0.868$ & $\mathbf{0 . 0 0 1}$ \\
\hline PLR & 0.714 & $0.645-0.783$ & $\mathbf{0 . 0 0 1}$ \\
\hline
\end{tabular}

ROC: Receiver operating characteristic, NLR: Neutrophil lymphocyte ratio, PLR: Platelet lymphocyte ratio

Table 3. Diagnostic value of NLR and PLR in detecting APE in patients with CKD

\begin{tabular}{|c|c|c|c|c|c|c|c|}
\hline & & Control group & Case group & Sensitivity & Positive prediction & Specificity & Negative prediction \\
\hline \multirow{2}{*}{ NLR } & $\leq 3.5$ & 92 & 32 & \multirow{2}{*}{$70.6 \%$} & \multirow{2}{*}{$84.6 \%$} & \multirow{2}{*}{$86.8 \%$} & \multirow{2}{*}{$74.2 \%$} \\
\hline & $>3.5$ & 14 & 77 & & & & \\
\hline PLR & $>125$ & 37 & 75 & $68.8 \%$ & $67.0 \%$ & $65.1 \%$ & $67.0 \%$ \\
\hline
\end{tabular}

NLR: Neutrophil lymphocyte ratio, PLR: Platelet lymphocyte ratio, APE: Acute pulmonary embolism, CKD: Chronic kidney disease 
pulmonary embolism was $171.9 \pm 77.2$. There was no significant difference in PLR values between cases with segmental and subsegmental pulmonary embolism $(p=0.957)$.

The mean PLR of cases with unilateral pulmonary embolism was $201.3 \pm 219.1$, and the mean of cases with bilateral pulmonary embolism was 194.4 \pm 130.3 , and there was no significant difference in PLR values between cases with unilateral and bilateral pulmonary embolism $(p=0.951)$.

NLR value did not differ significantly in the groups with and without DM, hypertension, DVT, and heart failure $(p=0.577, p=0.505, p=0.822$, $p=0.266$ )

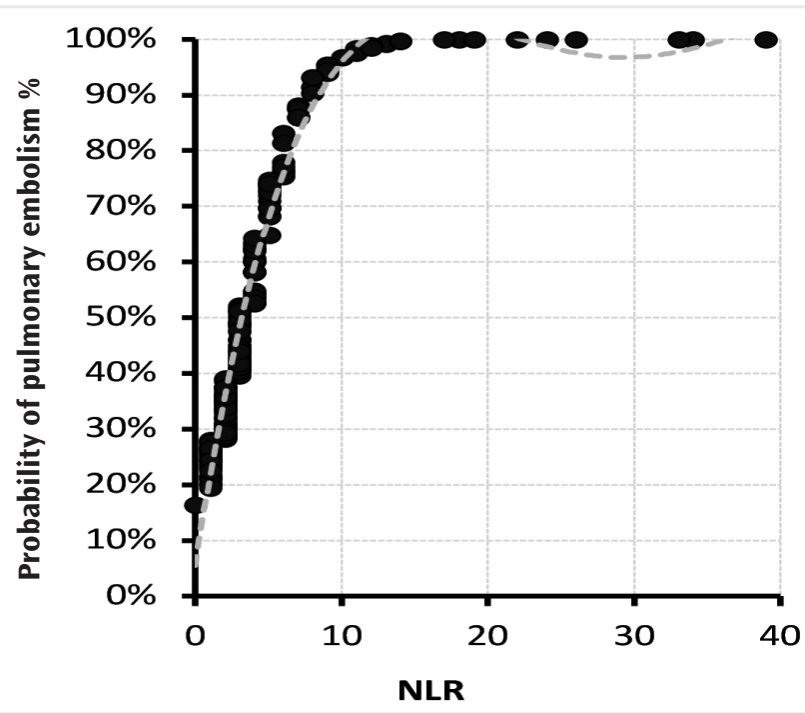

Figure 1. Probability of pulmonary embolism by NLR values NLR: Neutrophil lymphocyte ratio
When the relationship between GFR levels and NLR values of the patients in the case group was examined, the NLR value in the group with eGFR $<30 \mathrm{~mL} / \mathrm{min} / 1.73 \mathrm{~m}^{2}$ was found to be significantly lower than the group with eGFR between $60-90 \mathrm{~mL} / \mathrm{min} / 1.73 \mathrm{~m}^{2}(\mathrm{p}=0.010)$ (Table 4).

The PLR value did not differ significantly in the groups with and without DM, hypertension, heart failure, and DVT ( $p=0.904, p=0.051, p=0.745$, $p=0.529$ ) (Table 5). The PLR value did not differ significantly in the GFR groups ( $p=0.594)$ (Table 6).

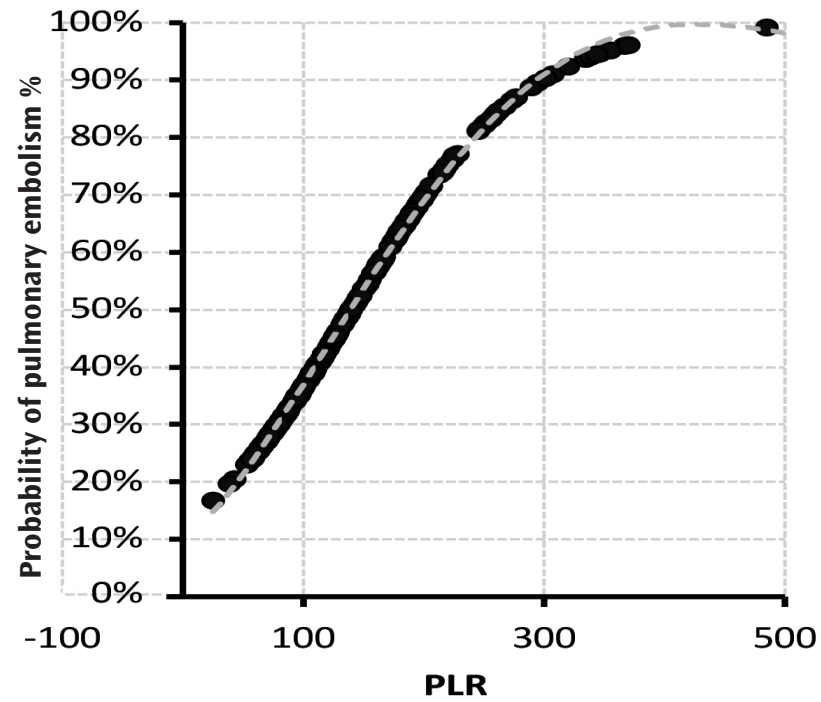

Figure 2. Probability of pulmonary embolism by PLR values PLR: Platelet lymphocyte ratio

Table 4. Relationship between pulmonary embolism severity and anatomical localization and NLR values

\begin{tabular}{|c|c|c|c|c|c|}
\hline & & NLR (min-max) & NLR (median) & NLR (mean \pm SD) $(n \%)$ & $p^{*}$ \\
\hline \multirow{2}{*}{ Severity } & \multirow{2}{*}{ Massive submassive } & $1.17-33.21$ & 4.9 & $6.8 \pm 6.4$ & \multirow{2}{*}{$0.372^{* *}$} \\
\hline & & $0.57-39.23$ & 4.1 & $6.3 \pm 7.1$ & \\
\hline \multirow{2}{*}{ Anatomical } & \multirow{2}{*}{ Segmental subsegmental } & $0.57-39.23$ & 4.3 & $6.6 \pm 6.6$ & \multirow{2}{*}{$0.349 * *$} \\
\hline & & $1.13-34.32$ & 4.5 & $6.3 \pm 7.8$ & \\
\hline \multirow{2}{*}{ Unilateral/bilateral } & \multirow{2}{*}{ Unilateral bilateral } & $0.81-34.32$ & 5.1 & $6.5 \pm 5.8$ & \multirow{2}{*}{$0.360 * *$} \\
\hline & & $0.57-39.23$ & 4.1 & $6.5 \pm 7.5$ & \\
\hline
\end{tabular}

NLR: Neutrophil lymphocyte ratio, ${ }^{*} \mathrm{p}<0.05$ was taken as the cut-off value of significance, ${ }^{* *}$ Calculated by Mann-Whitney U test, min: Minimum, max: Maximum, SD: Standard deviation

Table 5. Relationship between pulmonary embolism severity and anatomical localization and PLR values

\begin{tabular}{|c|c|c|c|c|c|}
\hline & & $\begin{array}{l}\text { PLR } \\
\text { (min-max) }\end{array}$ & PLR (median) & PLR (mean \pm SD) $(n \%)$ & $p^{*}$ \\
\hline Severity & $\begin{array}{l}\text { Massive } \\
\text { submassive }\end{array}$ & $\begin{array}{l}42.60-587.80 \\
38.66-1573.91\end{array}$ & $\begin{array}{l}152.6 \\
162.9\end{array}$ & $\begin{array}{l}193.9 \pm 116.0 \\
199.8 \pm 204.2\end{array}$ & $0.660 * *$ \\
\hline Anatomical & $\begin{array}{l}\text { Segmental } \\
\text { subsegmental }\end{array}$ & $\begin{array}{l}38.66-1573.91 \\
68.98-333.69\end{array}$ & $\begin{array}{l}161.1 \\
163.4\end{array}$ & $\begin{array}{l}203.6 \pm 190.0 \\
171.9 \pm 77.2\end{array}$ & $0.957^{* *}$ \\
\hline Unilateral/bilateral & Unilateral bilateral & $\begin{array}{l}38.66-1573.91 \\
42.60-681.82\end{array}$ & $\begin{array}{l}168.7 \\
152.6\end{array}$ & $\begin{array}{l}201.3 \pm 219.1 \\
194.4 \pm 130.3\end{array}$ & $0.951 * *$ \\
\hline
\end{tabular}

PLR: Platelet lymphocyte ratio, ${ }^{\star} p<0.05$ was taken as the cut-off value of significance, ${ }^{* *}$ Calculated by Mann-Whitney U test, min: Minimum, max: Maximum, SD: Standard deviation 
Table 6. Relationship between clinical conditions associated with pulmonary embolism and GFR level and PLR values

\begin{tabular}{|l|l|l|l|l|l|}
\hline & & PLR (min-max) & PLR (median) & PLR (mean \pm SD) (n\%) \\
\hline DM & $(-)$ & $60.91-587.80$ & 165.6 & $7.3 \pm 7.6$ \\
\hline HT & $(+)$ & $38.66-1573.91$ & 156.0 & $6.2 \pm 6.5$ \\
\hline CHF & $(-)$ & $38.66-587.80$ & 185.0 & $6.9 \pm 6.8$ \\
\hline & $(+)$ & $56.62-1573.91$ & 136.1 & $6.1 \pm 6.8$ \\
\hline DVT & $(-)$ & $42.60-587.80$ & 164.5 & $7.0 \pm 5.7$ \\
\hline & $(+)$ & $38.66-681.82$ & 159.4 & $6.3 \pm 7.2$ \\
\hline GFR & $(-)$ & $38.66-681.82$ & 136.1 & $7.1 \pm 9.2$ \\
\hline
\end{tabular}

DM: Diabetes mellitus, DVT: Deep vein thrombosis, GFR: Glomerular filtration rate, HT: Hypertension, CHF: Congestive heart failure, PLR: Platelet lymphocyte ratio, * $<<0.05$ was taken as the cut-off value of significance, ${ }^{* *}$ Calculated by Mann-Whitney u test, ${ }^{* * *}$ Calculated by Kruskal-Wallis test, min: Minimum, max: Maximum, SD: Standard deviation

\section{Discussion}

APE is a cardiovascular disease with high morbidity and mortality. It has been determined to be the most common cause of in-hospital sudden deaths and its annual incidence is 60-70/100,000 (4).

APE causes reperfusion injury, leading to an increase in oxidative stress, myeloperoxidase enzyme and reactive oxygen radicals in the lung. In addition, severe hypoxia caused by pulmonary artery vasoconstriction increases adrenergic and neurohormonal system activity. As a result, inflammatory cytokines are released and all these developments exacerbate the thrombosis (5). As in all atherothrombotic patients, inflammation has an important role in the pathophysiology of pulmonary embolism. The place of some inflammatory parameters has been demonstrated in studies. Among these parameters, B-type natriuretic peptide (BNP), N-terminal-proBNP, interleukin-6 (IL-6), IL-8, troponin and myoglobin can be counted $(6,7)$.

Afzal et al. (8) showed for the first time the increase in leukocytes in pulmonary embolism. In this study, it was revealed that neutrophils play an important role in the inflammatory response in atherosclerotic background (8). Leukocytes are associated with both thrombogenesis and an increase in fibrinogen, factor VII, and factor VIII levels (9).

In acute stress, lymphopenia is a frequent occurrence in the inflammatory response process (10). The increase in corticosteroid levels in stressful situations may be the reason for this. Pulmonary embolism is also an acute stress picture.

The key role of platelets in inflammation and thrombosis is known. Thus, the three hematological parameters -neutrophils, lymphocytes and platelets- are also used as inflammation parameters. PLR and neutrophil/ lymphocyte ratio (NLR) levels can indicate the severity of inflammation and correlate with the severe form of the disease. This situation has also been shown in cardiovascular diseases (11-13). Various studies have shown that PLR and NLR levels are associated with poor prognosis of many inflammatory diseases and malignancies (14). Relationships between cardiovascular diseases and prognosis have been studied in aortic valve replacement (15), coronary artery disease (16), non-valvular atrial fibrillation (17), and heart failure cases (18).

It has been shown in the studies of Yang and Liu (19) and Ferroni et al. (20) that PLR and NLR levels may be a marker of VTE. Again, in a study by Farah et al. (21), white blood cell, PLR, NLR values in the acute VTE group were found to be statistically significant and higher than the control group, and it was argued that NLR could be a useful marker for early detection of potential acute VTE.

Karataş et al. (22), in their retrospective study in our country, performed a mortality study of up to 20 months with 241 cases of APE. In this study, they found NLR $>5.93$ and PLR $>191$ cut-off values to be significant (22). Soylu et al. (23), on the other hand, studied only the level of NLR in in-hospital mortality. NLR was determined as $>5.7$ cut-off value (23). Ozcan Cetin et al. (24) followed 459 cases for 28.8 months and found PLR $>147.8$ to be significant (145). Ma et al. (25), on the other hand, found statistical significance at the level of NLR $>5.99$ and PLR $>325$, which they studied as markers in a 30-day mortality study. In our study, the mean NLR of patients with massive pulmonary embolism was 6.8 \pm 6.4 , and the mean PLR was 193.9 \pm 116.0 , which is in line with the literature.

In these studies, it has been shown that high NLR value increases short-term mortality approximately 9 times and overall mortality approximately 10 times. Again, high PLR value increases short-term mortality 7 times, long-term mortality 6 times and overall mortality 6 times (25).

In our study, a relationship was found between low hemoglobin level and the diagnosis of pulmonary embolism. When the hemogram values of the patients diagnosed with pulmonary embolism with chronic kidney disease (CKD) and those who did not have any additional disease other than CKD were compared, it was found to be significantly lower in the pulmonary embolism group. Anemia is an expected result in chronic renal failure, but cases with similar CKD stages were obtained in the case and control groups, thus eliminating the effect of CKD on anemia. There is no study in the literature showing the relationship 
between hemoglobin level and pulmonary embolism, but there are studies showing the negative effects of anemia on mortality in cases with pulmonary embolism (26). Again, age is an independent risk factor in Geneva criteria. The age factor can be associated with anemia, and it is known that the incidence of anemia increases with increasing age (27). In addition, tachycardia, which is included in the Wells pulmonary embolism clinical prediction scoring, may also be associated with anemia.

Contrast nephropathy is a concern for the clinician, especially in patients with impaired renal function. Our concerns on this issue are mostly shaped by data obtained from cardiac patients who have undergone radiological intervention. There is a study in the literature on the effect of CT pulmonary angiography on contrast nephropathy. Kwok detected contrast nephropathy cases in $41 \%$ and dialysis need in $26 \%$ after CT pulmonary angiography in APE cases with risk factors. They developed a contrast nephropathy risk score at the end of the study and do not recommend the application of $\mathrm{CT}$ pulmonary angiography if the risk score they determined exceeds 16 (28).

Pulmonary CT angiography, which is the gold standard test for pulmonary embolism, should be applied in patients with renal dysfunction considering the benefit-harm balance, and in this case, alternative diagnostic methods such as transthoracic echocardiography, lower extremity venous Doppler ultrasonography and V/Q scintigraphy gain importance. Due to the increase in procoagulant factors and decrease in renal elimination, the d-dimer level also increases in these patients and its clinical usefulness in the diagnosis of VTE decreases.

\section{Study Limitations}

The limitations of the study are that it is single-centered and retrospective, and the number of patients is small.

\section{Conclusion}

NLR and PLR values, which are simple indicators of the inflammatory response and inexpensive, easily calculated parameters, can be used in the diagnosis of suspected pulmonary embolism in patients with renal dysfunction, but should be supported by larger studies on the subject.

Ethics Committee Approval: The study protocol was approved by the University of Health Sciences Turkey, İstanbul Training and Research Hospital Local Ethics Committee (approval number: 1825, date: 10.05.2019).

Informed Consent: Retrospective study.

Peer-review: Externally and internally peer-reviewed.

Authorship Contributions: Surgical and Medical Practices - E.T.; Concept - M.E.P.; Design - M.E.P.; Data Collection or Processing - E.T.; Analysis or Interpretation - E.T.; Literature Search - E.T., M.E.P.; Writing - E.T., M.E.P.

Conflict of Interest: No conflict of interest was declared by the authors.

Financial Disclosure: The authors declared that this study received no financial support.

\section{References}

1. Turkish Thoracic Society. Pulmonary Thromboembolism Diagnosis and Treatment Consensus Report. Turkish Thoracic Journal; 2015.

2. Mohammed NMS, Khalil HBE. D-dimer levels in patients chronic kidney disease in Sudan. American Journal of Medicine Sciences 2016; 6:120-2.

3. Huang MJ, Wei RB, Wang Y, Su TY, Di P, Li QP, et al. Blood coagulation system in patients with chronic kidney disease: a prospective observational study. BMJ Open 2017; 7: e014294.

4. García-Sanz MT, Pena-Álvarez C, López-Landeiro P, Bermo-Domínguez A3, Fontúrbel T, González-Barcala FJ. Symptoms, location and prognosis of pulmonary embolism. Rev Port Pneumol 2014; 20: 194-9.

5. Zorlu A, Bektasoglu G, Guven FM, Dogan OT, Gucuk E, Ege MR, et al. Usefulness of admission red cell distribution width as a predictor of early mortality in patients with acute pulmonary embolism. Am J Cardiol 2012; 109: 128-34.

6. Kucher N, Goldhaber SZ. Cardiac biomarkers for risk stratification of patients with acute pulmonary embolism. Circulation 2003; 108: 2191-4.

7. Donzé J, Le Gal G, Fine MJ, Roy PM, Sanchez O, Verschuren F, et al. Prospective validation of the Pulmonary Embolism Severity Index. A clinical prognostic model for pulmonary embolism. Thromb Haemost 2008; 100: 943-8.

8. Afzal A, Noor HA, Gill SA, Brawner C, Stein PD. Leukocytosis in acute pulmonary embolism. Chest 1999; 115: 1329-32.

9. Bovill EG, Bild DE, Heiss G, Kuller LH, Lee MH, Rock R, et al. White blood cell counts in persons aged 65 years or more from the cardiovascular health study. Correlations with baseline clinical and demographic characteristics. Am J Epidemiol 1996; 143: 1107-15.

10. Hoffman M, Blum A, Baruch R, Kaplan E, Benjamin M. Leukocytes and coronary heart disease. Atherosclerosis 2004; 172: 1-6.

11. Temiz A, Gazi E, Güngör Ö, Barutçu A, Altun B, Bekler A, et al. Platelet/ lymphocyte ratio and risk of in-hospital mortality in patients with ST-elevated myocardial infarction. Med Sci Monit 2014; 20: 660-5.

12. Ghaffari S, Nadiri M, Pourafkari L, Sepehrvand N, Movasagpoor A, Rahmatvand $\mathrm{N}$, et al. The predictive value of total neutrophil count and neutrophil/ lymphocyte ratio in predicting in-hospital mortality and complications after STEMI. J Cardiovasc Thorac Res 2014; 6: 35-41.

13. Yildiz A, Yuksel M, Oylumlu M, Polat N, Akyuz A, Acet H, et al. The utility of the platelet-lymphocyte ratio for predicting no reflow in patients with ST-segment elevation myocardial infarction. Clin Appl Thromb Hemost 2015; 21: 223-8.

14. Balta S, Demırkol S, Kucuk U. The platelet lymphocyte ratio may be useful inflammatory indicator in clinical practice. Hemodial Int 2013; 17: 668-9.

15. Condado JF, Junpaparp P, Binongo JN, Lasanajak Y, Witzke-Sanz CF, Devireddy C, et al. Neutrophil-lymphocyte ratio (NLR) and platelet-lymphocyte ratio (PLR) can risk stratify patients in transcatheter aortic-valve replacement (TAVR). Int J Cardiol 2016; 223:444-9.

16. Sari I, Sunbul M, Mammadov C, Durmus E, Bozbay M, Kivrak T, et al. Relation of neutrophil-to-lymphocyte and platelet-to-lymphocyte ratio with coronary artery disease severity in patients undergoing coronary angiography. Kardiol Pol 2015; 73: 1310-6.

17. Yalcin M, Aparci Z, Uz O, Isilak Z, Balta S, Dogan M, et al. Neutrophillymphocyte ratio may predict left atrial thrombus in patients with nonvalvular atrial fibrillation. Clin Appl Thromb Hemost 2015; 21: 166-71.

18. Durmus E, Kivrak T, Gerin F, Sunbul M, Sari I, Erdogan O. Neutrophil-tolymphocyte ratio and platelet-to-lymphocyte ratio are predictors of heart failure. Arq Bras Cardiol 2015; 105: 606-13.

19. Yang W, Liu Y. Platelet-lymphocyte ratio is a predictor of venous thromboembolism in cancer patients. Thromb Res 2015; 136: 212-5. 
20. Ferroni P, Riondino S, Formica V, Cereda V, Tosetto L, La Farina F, et al. Venous thromboembolism risk prediction in ambulatory cancer patients: clinical significance of neutrophil/lymphocyte ratio and platelet/lymphocyte ratio. Int J Cancer 2015; 136: 1234-40.

21. Farah R, Nseir W, Kagansky D, Khamisy-Farah R. The role of neutrophillymphocyte ratio, and mean platelet volume in detecting patients with acute venous thromboembolism. J Clin Lab Anal 2020; 34: e23010.

22. Karataş MB, Ipek G, Onuk T, Güngör B, Durmuş G, Çanga Y, et al. Assessment of prognostic value of neutrophil to lymphocyte ratio and platelet to lymphocyte ratio in patients with pulmonary embolism. Acta Cardiol Sin 2016; 32: 313-20.

23. Soylu K, Gedikli Ö, Ekși A, Avcıoğlu Y, Soylu Ai, Yüksel S, et al. Neutrophil-tolymphocyte ratio for the assessment of hospital mortality in patients with acute pulmonary embolism. Arch Med Sci 2016; 12: 95-100.

24. Ozcan Cetin EH, Cetin MS, Canpolat U, Akdi A, Aras D, Temizhan A, et al. Platelet-to-lymphocyte ratio as a novel marker of in-hospital and long-term adverse outcomes among patients with acute pulmonary embolism: A single center large-scale study. Thromb Res 2017; 150: 33-40.

25. Ma $Y$, Mao $Y$, He X, Sun $Y$, Huang $S$, Qiu J. The values of neutrophil to lymphocyte ratio and platelet to lymphocyte ratio in predicting 30 day mortality in patients with acute pulmonary embolism. BMC Cardiovasc Disord 2016; 16: 123.

26. Wang Q, Ma J, Jiang Z, Ming L. Prognostic value of neutrophil -to-lymphocyte ratio and platelet-tolymphocyte ratio in acute pulmonary embolisym: a systematic review and metaanalysis. Int Angiol 2018; 37: 4-11.

27. Shah P, Arora S, Kumar V, Sharma S, Shah H, Tripathi B, et al. Short-term outcomes of pulmonary embolism: A national perspective. Clin Cardiol 2018; 41: 1214-24.

28. Ho KM, Harahsheh Y. Predicting contrastinduced nephropathy after CT pulmonary angiography in the critically ill: a retrospective cohort study. J Intensive Care 2018; 6: 3. 